JUSSI YLIKOSKI

Oulu

\title{
Remarks on the Saami demonstrative pronouns
}

\section{Introduction}

In the Festschrift for Y. H. Toivonen (1890-1956), a renowned etymologist and the professor of Finno-Ugric languages at the University of Helsinki, Knut Bergsland (1950) published a short paper entitled "Remarques sur les pronoms démonstratifs lapons". Seventy years later, this paper presents further remarks on Saami demonstratives, this time in honor of Toivonen's successor, Ulla-Maija Forsberg.

Contemporary linguistic typology provides new insights into Uralic demonstratives, and Uralic demonstratives are undoubtedly of interest to typologists. However, while Saami demonstratives have attracted the attention of later researchers as well, scholars have increasingly narrowed their focus to North Saami. Although the present paper also discusses the language with not only the most speakers but also the most demonstratives, it is shown and emphasized that North Saami is not the most representative Saami language in this respect. Although the typologically most interesting dialects have as many as six distinct demonstratives, most Saami languages and even some dialects of North Saami come with four demonstratives. However, as the number of such elements varies while the language-external world remains the same, most of the cognate elements have slightly distinct functions across languages. There is little variation in speaker-proximal demonstratives, but differences increase when speakers direct their attention to addressees and more distant referents.

The structure of the paper is as follows: After a brief introduction to the background and the state of research (Section 2), Section 3 presents data and observations on the demonstrative pronouns in the six most widely spoken Saami languages: North (3.I), Lule (3.2), South (3.3), Aanaar (3.4), Skolt (3.5) and Kildin Saami (3.6). 
Many of the examples belong in a cabinet of curiosities, exhibiting phenomena that have not been properly described earlier. Section 4 provides a general discussion and further remarks on the topic. Unless otherwise specified, the data presented in this study comes from authentic (in part translated) texts made available by the SIKOR corpus at UiT The Arctic University of Norway. Additional examples stem from other texts and observations from daily communication with native speakers. ${ }^{1}$

\section{Background}

As demonstratives generally belong to the oldest elements of a language, Saami demonstratives attracted the attention of the pioneers in Uralistics already in the early 19th century. However, as these elements belong to an intermediate zone outside lexical words and grammatical affixes, even etymologists of our time are divided over the exact relations of the demonstratives that nevertheless more or less directly go back to Proto-Uralic demonstratives such as ${ }^{*} t \ddot{a}$ - 'this' and ${ }^{*} t 8$ - 'that' (see e.g. Bergsland 1950; Kulonen 2005; Keresztes 20IO). While this paper remains fairly indifferent about the ultimate origins of Saami demonstratives, it appears probable that Proto-Saami had four demonstrative stems, all consisting of ${ }^{*} t V$ - and being the source of at least seven distinct demonstrative pronouns in the present-day Saami languages.

As regards synchronic descriptions of Saami demonstratives, perhaps the most widely known depiction is that provided in Table I.

\begin{tabular}{|c|c|c|c|c|c|}
\hline \multirow{2}{*}{ Anaphoric } & \multicolumn{4}{|c|}{ Demonstrative } \\
\cline { 2 - 6 } & \multicolumn{3}{|c|}{ Proximal } & \multicolumn{3}{c|}{ Distal } \\
\cline { 2 - 6 } & Near speaker & Near addressee & Far & Further & Further yet \\
\hline dat & dát & diet & duot & dot & $d u t$ \\
\hline
\end{tabular}

Table I. North Saami demonstrative pronouns according to Abondolo (1998: 27).

In principle, Abondolo's (1998: 27) description is a quite correct depiction of one variety of North Saami. However, some terminological and conceptual remarks are in order before delving into the subject matter itself. There exists an extensive body of literature on demonstratives, with competing and sometimes contradictory concepts. Phenomena known as "demonstratives" are usually deictically contrastive expressions

I. I wish to thank the anonymous reviewer of the paper for a number of helpful comments and suggestions, and especially Ante Aikio, Outi Guttorm, Ellen Oddveig Hætta, Markus Juutinen, Maja Lisa Kappfjell, Olle Kejonen, Eino Koponen, Marja-Liisa Olthuis, Pekka Sammallahti and Elisabeth Scheller for various pieces of information and their insightful thoughts on Saami demonstratives at different stages of my research. 
that have specific syntactic functions. Although the term "demonstrative" can be used to refer to many kinds of deictics, this paper is confined to expressions commonly and more exactly labeled as "demonstrative pronouns". To be even more exact, it is possible to distinguish between "pronominal demonstratives" and "adnominal demonstratives", the difference between the two being that the former are true pronouns substituting for a noun (phrase), and the latter occur as adnominal determiners, accompanying a coreferential noun (see e.g. Diessel 2013).

The six deictic elements in Table I occur in both functions: It is possible to call this article dát artibkal (with a noun preceded by an adnominal demonstrative), but it is equally possible to refer to the same entity as dát (pronominal demonstrative). While it would be logical to reserve the label "demonstrative pronoun" for the latter function as well, I refrain from doing this mostly because of the long tradition of calling elements such as dát simply "demonstrative pronouns" in Saami linguistics - in spite of the fact that the inflectional forms of the pronominal and adnominal demonstratives do differ from each other throughout the Saami languages, as seen in the North Saami locative phrases dás [this.LOC] 'in this; here' and dán artibkkalis [this.GENACC article.LOC] 'in this article' (for other Saami languages, see e.g. Magga \& Magga 2or2: 52-54; Feist 2016: I86-I87).

Moreover, in this paper I refer to these phenomena as "demonstratives" for short, not unlike many other scholars such as Abondolo in Table I. However, unlike Abondolo I do not see a reason to label elements such as dat 'that; it' as "anaphoric" in opposition to deictic elements called "demonstratives"; instead, I characterize words like dat as anaphoric demonstratives. Although Saami languages abound with dozens of other deictic elements that can be characterized as demonstratives, demonstrative adjectives such as North Saami dakkár 'like that', dákkár 'like this', diekkár 'like that (near addressee)' and duokkár 'like that over there', and analogous adverbs like nu, ná, nie and nuo, as well as emphatic variants of demonstrative pronouns (e.g. dábtanaga 'exactly this' and dabtanaga 'exactly that; selfsame') fall outside the scope of this paper (but see e.g. Nielsen 1947 and Sammallahti 2005: 236-240). This paper focuses on demonstrative pronouns that are morphologically opaque in the sense that their morphosyntactic makeup is not a sum of multiple elements.

To return to demonstrative systems such as the one depicted in Table I, they can be explained by following Diessel (2012: 2420) who describes languages like North Saami as having two different kinds of deictic centers. In addition to egocentric deixis in which the space is conceptualized from the hearer's point of view only, it is possible to share a common deictic center with the hearer, and from there to view one or more locations outside the shared domain. To apply Diessel's visualization of the demonstrative system in Hausa to that of North Saami, the five spatial and primarily non-anaphoric demonstratives can be described in Figure I, which, however, for the sake of completeness also shows the non-spatial, non-visible anaphoric demonstrative dat behind the dashed line on the left. 


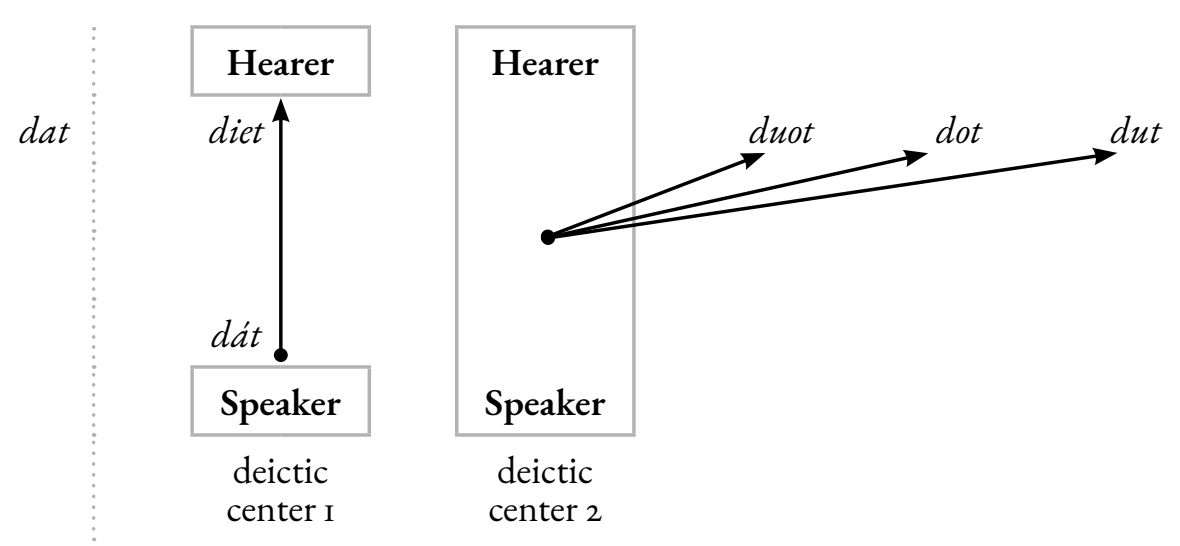

Figure I. The deictic centers of the North Saami demonstratives (cf. Table I and Diessel 2012: 2420).

Demonstratives have also many other functions besides the most primitive needs to refer to concrete objects that are visible within or outside different types of deictic centers. In fact, the most recent studies on North Saami demonstratives have focused on various discourse functions that are by no means limited to the most anaphoric and least visible pronoun. As shown by Guttorm (2009, 2015, 2019), all of the five most common North Saami demonstratives have also anaphoric functions, nuances of which correlate with the deictic functions of these elements. Other Saami languages appear to function in similar ways, but with the exception of Guttorm's studies, virtually all existing descriptions of Saami demonstratives focus on the most concrete deictic functions. Such descriptions are quite scanty, however; demonstratives are only routinely briefly mentioned in grammars, and as words they are also recorded in dictionaries.

To my knowledge, there are only three brief publications focusing on Saami demonstratives as a whole. Bergsland (1950), Kont (1970) and Keresztes (2010) are primarily interested in the historical development of the Saami demonstrative stems. The topic is also discussed by Larjavaara (1986: 69-75) in his study on Finnic demonstratives. While the main interests of the present paper are not diachronic, I will return to certain issues discussed by the aforementioned scholars, mainly in Section 4. However, diachronic reflections must be based on our synchronic understanding of the given phenomenon, and it appears that more can be done in order to understand Saami demonstratives. Regardless of our ultimate aims, North Saami is only one of the many individual Saami languages, and this is why the present paper attempts to provide a concise and uniform picture of the main features of the demonstratives in the six most vital Saami languages. 


\section{Demonstratives in individual languages}

\section{I. North Saami}

The six-term demonstrative system seen above is, admittedly, a fascinating inventory of Saami demonstrative pronouns. Although the theoretical framework of this discussion is largely that of Diessel (2012, 2013), it must be noted that the North Saami six-term demonstrative system seen above does not equal to a hypothetical six-term system in Diessel's (2013) WALS chapter on distance contrasts in demonstratives: One of the six demonstratives in North Saami is the anaphoric dat 'that; it', which usually refers to referents that are not visible. In other words, North Saami as such has "only" a five-way distance contrast, but this is definitely enough to make the language quite exceptional both within Uralic and globally. In Diessel's balanced sample of 234 languages, there are only four languages with comparable five-way distance contrasts (Koasati, Maricopa and Navajo spoken in southern parts of the USA, Malagasy in Madagascar), and to my knowledge, none of the about forty other Uralic languages have similar systems, but mostly two- or three-way contrasts instead.

Despite the attractiveness of such an extreme demonstrative system in the eyes of typologists, it must be pointed out that although the six demonstratives are quite regularly described in the most important dictionaries and grammars (e.g., Nielsen 1926: I25-I26; Sammallahti 2005: 236; Sammallahti \& Nickel 2006 s.v.) as well as in the aforementioned studies focusing on the demonstratives, the existence of the most distal pronoun, $d u t$ is debatable. To put it shortly, I have not been able to attest this pronoun in authentic use anywhere in more than 50 million words of North Saami texts. True, most of the written texts concentrate on issues where there is little need for typologically extraordinary demonstratives with the meaning 'that ... very far away' (as translated by Nielsen 1932-1962 s.v. düt, as opposed to $d o t$ ' that one far away over there' and duot 'that one over there'), but it is even more remarkable that $d u t$ is foreign to a large majority of the present-day speakers of North Saami. In fact, the word has perhaps never been in use outside the Deatnu river valley in the eastern inland dialect area of the language. The pronoun was first documented by Nielsen (1926: I26; 1932-1962 s.v.) in Buolbmát and Kárášjohka on the Norwegian side of the North Saami territory, but it is also used in the Finnish Ohcejohka (Pekka Sammallahti, p.c.). However, dut is clearly a highly marginal element even in its homeland, and especially younger speakers can regard it as a variant of duot at best. On the other hand, it is still possible to elicit sentences such as (I):

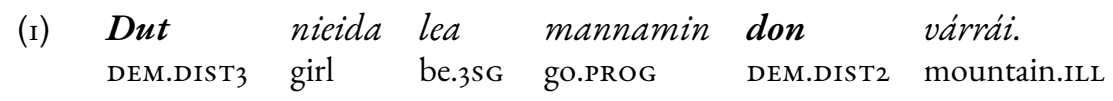

'That girl very far away over there is going to that mountain over there.' (N.N., p.c.) 
Those who know $d u t$ describe its meaning unanimously: According to Kåven et al. (1995), dut is 'that one (which is very far away but still visible)', and an anonymous speaker explains as follows: "Dut is farther away than dot. Dut is farthest among those that are visible” (N.N., p.c.). However, this does not take away the fact that (I) above is the first example sentence ever presented for $d u t$, and even that has been elicited. On the other hand, it is obvious that this is a true element of some vernaculars, and it has been in use for at least a century. In fact, it appears that during the past century $d u t$ has experienced changes that have actually integrated it better into the demonstrative system as a whole.

The outlier nature of $d u t$ has been understood by earlier scholars such as Nielsen (1932-1962 s.v. $d \bar{u} t)$ who recorded the word as having the forms [Dūi $\mathrm{h}$ ] (Buolbmát) and [D $\left.\bar{u}^{\mathrm{h}} \mathrm{k}\right]$ (Kárášjohka), which can be interpreted phonologically as / tuuuh/. However, the vowel $/ \mathrm{w} /$ has otherwise been absent in classical North Saami, although the continuous flood of Scandinavian loanwords during the past century appears to have given it the status of an independent phoneme in the bilingual speech communities of Norway and Sweden. As noted by Bergsland (1950: 31), this kind of pronunciation has undoubtedly had an unusually expressive and innovative flavor in the basic vocabulary. However, among those who still use the word it is no longer /tumb/ but /tuuh/, which is fully in line with the traditional phonology. Moreover, although Bergsland remarked that $d u t$ differs from the rest of the demonstratives in not having corresponding local adverbs, Guttorm (1992: 2) has later provided an example of the local demonstrative adverb duppe 'over there very far away', on a par with less distal adverbs like doppe and duoppe. While the use of $d u t$ has remained extremely marginal, it appears to have simultaneously gained a firmer foothold in the language of those who still use it.

As regards other distal demonstratives, it must be emphasized that the semantic difference between duot and dot is relative, not absolute. Different speakers may choose to use different demonstratives when referring to identical referents in an identical landscape. Moreover, use of the most distal demonstrative in the western dialects, $d o t$, is obviously dependent on other landmarks. As one speaker put it, the referent of dot rukses viessu 'that red house far away over there' among dozens of houses within a distance of about one kilometer would nevertheless rather be characterized as duot rukses viessu 'that red house over there', were there not two other red houses (duot guokte rukses viesu) in the foreground, making the house in question best identifiable as $d o t$ - the one farther in the background but prominent enough to be identified (N.N., p.c.).

Not even the non-distal demonstratives dat, dát and diet are fully unproblematic, if North Saami is viewed outside the standardized language based on the inland dialects spoken in Norway and Finland. As will be seen in Section 3.2 below, the demonstratives in Lule Saami resemble those of North Saami, but the main difference is the lack of the specifically hearer-oriented demonstrative diet, the functions of which 
are mostly carried out by the otherwise anaphoric dat. However, as regards the southwesternmost fringes in the so-called Torne Saami dialect spoken in Norrbotten and the corresponding dialects spoken in the districts of Ofoten and Sør-Troms in Norway, the border between North Saami and Lule Saami vernaculars is not clear-cut, and this is also true for demonstratives: diet has earlier been absent in the dialect of Čohkkiras and south of it, although it seems to have later gained ground due to the increasing influence of the Finnmark dialects and their role as the basis of the literary language (Collinder 1949: 250; Bergsland 1950: 31).

In conclusion, instead of the demonstrative system seen in Table I and Figure I, it is more appropriate to present the demonstratives in North Saami as a continuum in Table 2, which not only takes into account the highly marginal role of $d u t$ in North Saami in general, but also acknowledges that also diet is foreign to the southwesternmost vernaculars. (For descriptive purposes, the columns for speaker-oriented and addressee-oriented demonstratives in Table 2 and the tables that follow are ordered differently from those of Abondolo's (1998) Table i seen above.)

\begin{tabular}{|c|c|c|c|c|c|}
\hline \multirow{2}{*}{ Anaphoric } & \multicolumn{4}{|c|}{ Deictic } \\
\cline { 2 - 6 } & \multicolumn{2}{|c|}{ Proximal } & \multicolumn{3}{c|}{ Distal } \\
\cline { 2 - 6 } & Near addressee & Near speaker & Far & Further & Further yet \\
\hline \multirow{2}{*}{$d a t$} & diet $^{\mathrm{a}}($ dat $)$ & dát $^{\mathrm{d}}$ & duot & dot & $(d u t)^{\mathrm{b}}$ \\
\hline
\end{tabular}

Table 2. North Saami demonstrative pronouns.

a Foreign to the southernmost traditional dialects.

b Foreign to most speakers, but occasionally used in the easternmost dialects spoken along the Deatnu river.

In spite of the above adjustments in the description of the North Saami demonstrative system, the language in general has an extraordinarily high number of demonstrative stems, and some of the easternmost dialects still do have a six-term system, which may be richer than in any other languages of the Uralic family or elsewhere in Europe.

\subsection{Lule Saami}

The demonstratives in Lule Saami are quite like those of North Saami, and apparently identical with those of its southwesternmost vernaculars (Table 3). The only visible difference between the four Lule Saami demonstratives and their North Saami cognates is orthographic: the vowels in Lule Saami dat and North Saami dot both stand for $/ \mathrm{oo} /$. 


\begin{tabular}{|c|c|c|c|c|}
\hline \multirow{3}{*}{ Anaphoric } & \multicolumn{4}{|c|}{ Deictic } \\
\cline { 2 - 5 } & \multicolumn{2}{|c|}{ Proximal } & Far & Further \\
\cline { 2 - 5 } & Near addressee & Near speaker & duot & dàt \\
\hline
\end{tabular}

Table 3. Lule Saami demonstrative pronouns.

The functions of the Lule Saami demonstratives are so similar to those of North Saami that the only remarkable difference is the total absence of a specifically speaker-oriented pronoun akin to North Saami diet. As seen in the translation (2b) of a North Saami children's book (2a), the otherwise anaphoric dat is used instead:

(2a) Mii ipmašiid diet=ges lea? Lebpet go goržžzi

what wonder.PL.GENACC DEM.ADDR=DPT be.3SG be.2PL Q waterfall.GENACC

$\begin{array}{lllll}\text { coggan } & \text { dien } & \text { dingga } & \text { sisa, jearrá son. } \\ \text { stuff.PTCP.PST } & \text { DEM.ADDR.GENACC } & \text { thing.GENACC } & \text { into ask.3SG } & \text { 3SG }\end{array}$

(2b) Mij ibmabijt la gis dat?

what wonder.PL.ACC be.3SG DPT DEM.AN

Libpitgus gårtjev dan sisi tsåggåm, gatját sån.

be.2PL Q waterfall.ACC DEM.AN.GEN into stuff.PTCP.PST ask.3SG 3SG

'What in the world is that? Have you stuffed

a waterfall into that thing [a water tap], she asks.' (Olsen 1994a: 22; 1994b: 22)

Countless similar examples could be provided from authentic language use, but as North Saami diet simply lacks cognates in Lule Saami, dat is used also in translations and cannot be dismissed as translational interference.

The existing school grammars do not pay attention to less deictic anaphoric functions of the primarily deictic demonstratives such as duot and dat, but these are also possible just like in North Saami. In (3) from a short story, the speaker is referring to people met earlier in the day, and to a particular yet now absent girl who has potentially been seen by the addressee.
(3) Vuojnni
gus din,
$2 S G$
Biehtár,
Biehtár
duov
fávros
see.PST.2SG

Tsoabkeluovtas?

nejtsov

Tsoabkeluovtas?
Tsoahkeluokta.ELA

girl.ACC

'Biehtár, did you see that beautiful girl from Tsoahkeluokta?' 


\subsection{South Saami}

Despite the differences in the outward appearance of the demonstratives, the South Saami system as a whole is mostly similar to that of Lule Saami (Table 4).

\begin{tabular}{|l|c|c|c|c|}
\hline \multirow{2}{*}{ Anaphoric } & \multicolumn{3}{|c|}{ Deictic } \\
\cline { 2 - 5 } & \multicolumn{2}{|c|}{ Proximal } & \multicolumn{2}{c|}{ Distal } \\
\cline { 2 - 5 } & Near addressee & Near speaker & Far & Further \\
\hline dihte (dobte) & doete $($ dihte $)$ & daate & doete & dobte \\
\hline
\end{tabular}

Table 4. South Saami demonstrative pronouns.

South Saami is not entirely similar to Lule Saami, though. Most importantly, the existing school grammars and dictionaries usually describe doete as referring to objects near the addressee (e.g. Magga \& Magga 20I2: 52-54). Although it appears that in actual language usage another demonstrative that can be characterized as addressee-oriented is dibte ( dibte), the cognate of Lule and North Saami dat, and although doete 'that over there' often behaves quite like duot in Lule and North Saami, it indeed also seems to be the default addressee-oriented demonstrative in South Saami. A primary school reader presents the following illustrative examples:

(4a) Daate garja lea mov. DEM.SPKR book be.3SG ISG.GEN

'This book is mine.'

(4b) Doete gerja lea dov. DEM.ADDR/DISTI book be.3SG 2SG.GEN

'That book (near you/over there) is yours.'

(4c) Dobte garja Pieren.

DEM.DisT2 book Piere.gen

'That book [likely visible, far away over there] is Piere's.'

(4d) Dibte garja Birjen.

DEM.AN book Birje.GEN

'That book [likely not visible] is Birje's.'

(Jacobsen 1996: 3I)

However, the following example nicely illustrates the fact that the North Saami addressee-oriented diet (2a) - translated into Lule Saami with dat (2b) - can be translated with not only doete (genitive doen) but also dibte in South Saami (2c): 


\section{$\begin{array}{llllll}\text { (2c) } & \text { Mij } & \text { dibte? } & \text { Fuersiem } & \text { doen } & \text { aten } \\ \text { what } & \text { DEM.AN } & \text { waterfall.ACC } & \text { DEM.ADDR.GEN } & \text { thing.GEN }\end{array}$ \\ sijse biejeme? \\ into put.PTCP.PST}

'What is that? Have you stuffed a waterfall into that thing?' (Olsen 1994c: 22)

South Saami has other special features as well, as dibte has two central functions that make it somewhat different from dat in its northern sister languages: it has mostly taken over the functions of the pronoun satne '(s)he' and is now regarded as the primary third-person pronoun (including plural dab), and on the other hand it is also frequently used as a kind of definite article (Bergsland 1946: I06-I07; Magga \& Magga 2012: 223). These functions are by no means foreign to Lule and North Saami dat either, but their major functions are still indisputably those of demonstratives.

The cognate of Lule Saami dat and North Saami dot is also quite different. As noted already by Bergsland (1946: 105-106; 1950: 31), dobte is not only a distal deictic but also has many anaphoric functions. In Bergsland's view, dohte can be described as a distal counterpart of dibte in the sense that the former is specifically used to refer to referents that are either concretely or figuratively not only out of reach but also out of sight, often temporally belonging to the relatively distant past or future, or being a topic that has been mentioned only earlier in discourse. In addition to examples presented by Bergsland, the distancing yet dibte-like usage of dobte is also illustrated in (5), where dibte and dobte are in the genitive, dan and don, respectively:

(5)

\begin{tabular}{|c|c|c|c|c|}
\hline $\begin{array}{l}\text { Dan } \\
\text { DEM.AN.GEN }\end{array}$ & $\begin{array}{l}\text { akten } \\
\text { one.GEN }\end{array}$ & $\begin{array}{l}\text { nomme } \\
\text { name }\end{array}$ & $\begin{array}{l}\text { Tjekkija } \\
\text { Czech }\end{array}$ & $\begin{array}{l}\text { jib } \\
\text { and }\end{array}$ \\
\hline $\begin{array}{l}\text { don } \\
\text { DEM.DIST2.GEN }\end{array}$ & $\begin{array}{l}\text { mubpien } \\
\text { another.GEN }\end{array}$ & $\begin{array}{l}\text { bielien } \\
\text { half.GEN }\end{array}$ & $\begin{array}{l}\text { nomme } \\
\text { name }\end{array}$ & $\begin{array}{l}\text { Slovakija. } \\
\text { Slovakia }\end{array}$ \\
\hline
\end{tabular}

The relative frequency of dobte in various subcorpora of SIKOR is significantly higher than that of its cognates in other Saami languages, and it appears that dobte is the South Saami demonstrative that deserves most attention in future studies; I will return to the relations of dibte and dobte in Section 4 below. 


\subsection{Aanaar Saami}

Turning our attention now to languages east of North Saami, its closest neighbor is Aanaar Saami. In the only existing grammar of the language, Olthuis (2000: 157-158) mentions four demonstratives, but also a fifth one exists (Table $\varsigma$ ).

\begin{tabular}{|c|c|c|c|c|}
\hline \multirow{2}{*}{ Anaphoric } & \multicolumn{4}{|c|}{ Deictic } \\
\cline { 2 - 5 } & \multicolumn{2}{|c|}{ Proximal } & \multicolumn{2}{c|}{ Distal } \\
\cline { 2 - 5 } & Near addressee & Near speaker & Far & Further \\
\hline \multirow{2}{*}{ tot } & tiet $($ tot $)$ & taat & tuot & $($ tovt $)$ \\
\hline
\end{tabular}

Table 5. Aanaar Saami demonstrative pronouns.

The Aanaar Saami demonstrative system is quite similar to that of North Saami, but there are no traces of a sixth, extremely distant demonstrative like $d u t$. Instead, even the fifth one is very marginal, nowadays mainly occurring only in petrified expressions like toun pel(n) tounpel(n) 'on the other side' (Marja-Liisa Olthuis, p.c.). However, examples of adnominal and independent tovt can also be found:

(6) Mii=ks tovt lii, puásui vâi kumppi? what=DPT DEM.DIST2 be.3SG reindeer or wolf

'What is that? A reindeer or a wolf?'

(ILW s.v. tovt)

$\begin{array}{lllll}\text { (7) Siämmáá ääigi } & \text { hoksájim } & \text { maadij tobbeen viestârist, } \\ \text { same.GEN } & \text { time.GEN } & \text { notice.PST.ISG } & \text { road.ACC there } & \text { west.LOC }\end{array}$

ko tot mana Kuálsiuáivi paijeel já cyeigejim:

as DEM.AN go.3SG Kuálsiuáivi.gen over and remark.Pst.3SG

- Tovt maadij lii alda ton

DEM.DIST2 road be.3SG near DEM.AN.GEN

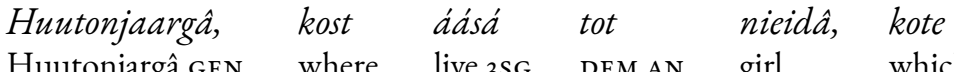

Huutonjargâ.GeN where live.3sg DEM.AN girl which

lii šoddâm muin siämmáá peeivi

be.3SG be.born.Pst.PTCP ISG.COM same.GeN day.GEN

tobbeen Ylivieska evakkost.

there Ylivieska.gen evacuation.Loc

'At the same time I noticed a road in the west, as it goes over Kuálsiuáivi, and I burst out: That road far away over there is near Huutonjargâ, where lives the girl who was born on the same day with me while being evacuated in Ylivieska.' 
Although not mentioned by Keresztes (2010), tovt is apparently a cognate of North Saami dot (cf. Bergsland 1950: 29-3I), but its semantics and frequency seem to come close to that of $d u t$ (cf. ILW s.v.: "der weiter entfernt liegt und undeutlich zu sehen ist").

Another demonstrative that is much less common in Aanaar Saami is tiet. Although Olthuis (2000: 157 ) and the existing dictionaries rightfully describe it as the addressee-oriented demonstrative (8), the anaphoric tot is also widely, if not more often, used in the same function (9):

$\begin{array}{llll}\text { Mii } & \text { lavluid } & \text { tiet } & \text { lii? } \\ \text { what } & \text { song.PL.ACC } & \text { DEM.ADDR } & \text { be.3SG }\end{array}$

'What song is that [the one you are singing]?'

(Jansson 2orgb: 23)

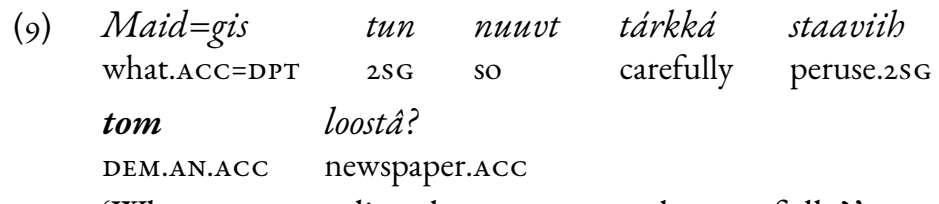

'Why are you reading that newspaper that carefully?'

The dual nature of tot seen in both (7) and (9) is analogous to that of Lule Saami dat (2b) and South Saami dibte in (2c) and (5), but also se in Finnish. The fact that Aanaar Saami has both the addressee-oriented tiet and a more distal tovt, but nevertheless could apparently do without them, suggests that the maximal five-term system, corresponding to that of the mainstream North Saami, is potentially being replaced by a three-term system analogous to that of Finnish, the language that has greatly influenced Aanaar Saami both during the extensive language shift to Finnish and later back to Aanaar Saami.

\subsection{Skolt Saami}

From the traditional historical-phonological perspective, the most important language boundary within the Saami branch is that between North and Aanaar Saami, but from a lexical and communicative point of view, Aanaar Saami is closer to North Saami than to Skolt Saami (see Rydving 2013), and this seems to be true for demonstratives as well. Only three of the five Aanaar and North Saami demonstratives have clear cognates in Skolt Saami, but it is customary to present a fourth demonstrative as well (Table 6). 


\begin{tabular}{|c|c|c|c|}
\hline \multirow{3}{*}{ Anaphoric } & \multicolumn{2}{|c|}{ Deictic } \\
\cline { 2 - 4 } & \multicolumn{2}{|c|}{ Proximal } & \multirow{2}{*}{ Distal } \\
\cline { 2 - 4 } & Near addressee & Near speaker & \\
\hline \multirow{2}{*}{ tôt } & tät tiet-aa & tut \\
\hline
\end{tabular}

Table 6. Skolt Saami demonstrative pronouns.

The most striking element in Table 6 is tiet-aa, whose appearance resembles the addressee-oriented tiet and diet in Aanaar and North Saami. However, in Skolt Saami this function is reserved for the otherwise anaphoric tôt (Io) (cf. 8 above):
(Iо) $M i$
laaul
tôt
DEM.AN be.3SG
what song
lij?
'What song is that [the one you are singing]?'

(Jansson 2019a: 23)

Without tiet-aa, we would be dealing with the simplest demonstrative system seen thus far. There is only one distal demonstrative (tut), and its speaker-oriented counterpart is almost always tät. In fact, the three-term system tôt - tät - tut is the one provided by Feist (2016: 108-109, 170-I7I) in the most comprehensive Skolt Saami grammar ever. However, virtually all other sources present the four-term system depicted in Table 6: Since Korhonen et al. (1973: 64), dictionaries and school grammars (e.g. Moshnikoff et al. 2009: 57, 66) have also mentioned tiet-aa (tiettaa) with the meaning 'this here' (Finnish tämä tässä). Strangely enough, Feist does not even comment on the claims about tiet-aa. However, tiet-aa seems to be very marginal, occurring only in spoken language corpora, and not often with obvious speaker-oriented function:
(II)

\begin{tabular}{llll} 
Mõozz mij & \multicolumn{2}{c}{ tien-aa } & vuä'mm \\
why IPL & DEM.SPKR.ACC & old \\
vaa'ldim, & tõt & pâi & reäkk. \\
take.PST.IPL & DEM.AN & only & cry.3SG
\end{tabular}
'Why did we take this old man here, he's only crying.'

On the other hand, the language otherwise has and uses the possibility to combine the focus particle - aa with other demonstratives, as also seen in some of Feist's (2016) examples. With its allegedly emphatic meaning, tiet-aa is obviously related to expressions like tôt-aa [DEM.AN-aa] 'just that; just it', but in the absence of an independent demonstrative *tiet in Skolt Saami, tiet-aa is a more or less opaque element of its own. Despite its marginal role in the language, tiet-aa makes the Skolt Saami demonstrative system unique among the Saami languages. 
An even more poorly studied spoken-language phenomenon is the use of dõot $\sim$ dott, apparently originally a variant of the demonstrative tôt , as a kind of hesitation pronoun used when the speaker cannot think of a particular noun (Juutinen 2016: 62):
(I2) $A \dot{a}$
öolgskuätt
dõot...
biâvted, Pe'll
$\hat{a} \operatorname{lgg}$
biâvted.
now must.INCH.3SG
HES
kill.InF Pe'll
must.3sG
kill.INF
'That [one] must be killed, that... that Pe'll must be killed.'

Although dõot seems to differ from demonstratives proper, this phenomenon - unique in Saami if not in all of Uralic - is definitely deserving of further research.

\subsection{Kildin Saami}

The last language in this survey is Kildin Saami, described mostly by Kert (197I), Kuruč (1985) and Antonova (2014). Despite some incongruities, the picture that emerges from these sources is that depicted in Table 7 .

\begin{tabular}{|c|c|c|c|c|}
\hline \multirow[t]{3}{*}{ Anaphoric } & \multicolumn{4}{|c|}{ Deictic } \\
\hline & \multicolumn{2}{|c|}{ Proximal } & \multicolumn{2}{|c|}{ Distal } \\
\hline & Near addressee & Near speaker & Far & Further \\
\hline \multicolumn{2}{|c|}{$m \ni \partial m$} & $m \bar{a} \partial m$ & $m y \partial m$ & мёлләдтӥ \\
\hline
\end{tabular}

Table 7. Kildin Saami demonstrative pronouns.

The Kildin Saami demonstrative system seems identical to that of Lule Saami. From a diachronic point of view, the main difference is that the most distal demonstrative mëллəдmə̈ is not a direct cognate of Lule Saami dåt or any other demonstrative discussed above. Due to the scarcity of descriptions and readily available research

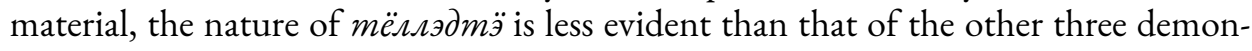
stratives, but according to Kuruč (1985: 349, 547), for example, mёллəдmə̈ expresses a remarkable, or the farthest, distance from the speaker. Only Antonova provides example sentences (13):

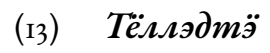
DEM.DIST2

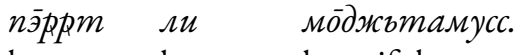

$$
\begin{aligned}
& \text { house be.3sg beautiful.sup }
\end{aligned}
$$

'That house over there is the most beautiful.'

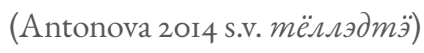

From a historical point of view, mёллəдmə̈ is only distantly related to its semantic counterparts such as North Saami dot. Its origin seems partly unclear, but it is evidently related to the adverb mёллэ 'over there (distant)' and an earlier demonstrative, perhaps also followed by a vocalic suffix akin to Skolt Saami tiet-aa. 


\section{Discussion and conclusion}

In conclusion, the contents of Tables $2-7$ can be summarized in Table 8.

\begin{tabular}{|c|c|c|c|c|c|c|}
\hline \multirow[t]{3}{*}{ Language } & \multirow[t]{3}{*}{ Anaphoric } & \multicolumn{5}{|c|}{ Deictic } \\
\hline & & \multicolumn{2}{|c|}{ Proximal } & \multicolumn{3}{|c|}{ Distal } \\
\hline & & Near addressee & Near speaker & Far & Further & Further yet \\
\hline South & dibte (dobte) & $\operatorname{doete}($ dihte $)$ & daate & doete & \multicolumn{2}{|c|}{ dobte } \\
\hline Lule & \multicolumn{2}{|l|}{ dat } & dát & $d u o t$ & \multicolumn{2}{|l|}{ dåt } \\
\hline North & $d a t$ & $\operatorname{diet}(d a t)$ & $d a ́ t$ & $d u o t$ & $d o t$ & $(d u t)$ \\
\hline Aanaar & tot & tiet $($ tot $)$ & taat & tuot & \multicolumn{2}{|l|}{$(t o v t)$} \\
\hline Skolt & \multicolumn{2}{|l|}{$t \tilde{t} t$} & tät tiet-aa & \multicolumn{3}{|l|}{ tut } \\
\hline Kildin & \multicolumn{2}{|l|}{$m \ni \partial m$} & $m \bar{a} \partial m$ & $m y \partial m$ & \multicolumn{2}{|c|}{ 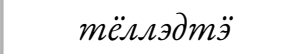 } \\
\hline
\end{tabular}

Table 8. Demonstrative pronouns in six Saami languages.

Table 8 offers, by necessity, rather broad generalizations, but these can nevertheless be used to make further generalizations. The table shows that Saami demonstrative systems are quite variegated. As already mentioned, the six-term distinction presented by Abondolo (1998) is marginal and found only in certain dialects of North Saami. While fascinating from a typological point of view, this system definitely does not represent the Saami group as a whole, hardly even North Saami itself. ${ }^{2}$ The southwesternmost dialects of North Saami have only four demonstratives, and this is actually the most common number of such elements in Saami. ${ }^{3}$ The four-term systems are not mutually uniform either, and it may be added that according to Tereškin (2002: IIO), present-day Ter Saami has only two demonstratives, which may be quite possible in a moribund language surrounded by Russian; more research may be needed.

\footnotetext{
2. But however marginal, the six-term system with a five-way distance contrast is still a fact in at least some eastern dialects spoken along the Deatnu River, and this cannot be refuted by Larjavaara's (2003: 467) perplexing statement that if language typologists are right in saying that such languages are universally nonexistent, the claims about the most extreme demonstrative systems in Saami are in need of revision.

3. For the sake of completeness it may be mentioned that in the contemporary western inland dialects of North Saami, most notably in Guovdageaidnu in the heart of the North Saami language area, the distinction between the anaphoric dat /tah/ 'that; it' and speaker-oriented dát/taah/ 'this' appears to be blurring. Misspellings or deviations from the standard orthography are highly frequent both ways, and it is often difficult distinguish between the two in spoken discourse (cf. Guttorm 2019: I49-I50). A similar situation has been reported in Pite Saami (see Lehtiranta 1992: 134). Interestingly, Keresztes (2010: 294-295) proposes that the pan-Saami distinction between the two is a result of an earlier split of the unstressed and stressed emphatic allomorphs of a single demonstrative.
} 
When Saami demonstratives are classified into the deictic categories seen in Table 8 and its predecessors, the most specialized - and, as it seems, diachronically most stable - demonstratives are those that refer to referents near the speaker. Only Skolt Saami has two speaker-oriented demonstratives, but other languages manage with one and generally do not use it for other purposes. Most languages also have separate demonstratives for prototypically distal (but visible) and anaphorical functions, although elements of the former type can also be used anaphorically; this is particularly characteristic for South Saami dohte. Two closely connected languages, Aanaar and North Saami, have specifically addressee-oriented demonstratives, but a distinction between two distal demonstratives is more common, fully lacking in Skolt Saami only, though in decline in Aanaar Saami as well. It seems that the easternmost languages have gradually lost the distinction between the two, but Kildin Saami has reinforced it through the emergence of mёлләдmə̈.

It has not been possible to focus on the relative frequencies of the demonstratives, but even though they often have a quite symmetrical outward appearance, many languages clearly have "minor demonstratives" in much less central positions than their "major demonstratives". It appears that North, Aanaar and Skolt Saami could do quite well without $d u t$, tovt and tiet-aa, respectively. However, the Saami languages generally make use of the possibilities of all kinds of demonstratives (including adjectives, adverbs and even verbs), as has been explicitly celebrated by Nielsen (1947: 45) and Magga (2013: 85-89) who attribute this "specializing tendency", à la Benjamin Lee Whorf, to the specific nature of the Saami as a "people of observation".

Unlike earlier surveys on the Saami demonstratives as a whole, the above observations have not focused on the diachronic development of these elements, but some remarks can be made. There is still no consensus on the origins of various Saami demonstratives, even though most of them can be related to comparable elements in other Uralic languages. Some of Bergsland's (1950) theoretical premises must be dismissed as outdated, as he appears to believe that the number of deictics in a language partly correlates with the degree of civilization of its speakers (e.g. Latin bic, iste, ille, but French celui-ci, celui-là). However, it is striking that while our typological understanding of demonstratives has gradually increased, Larjavaara (1986: 69-75) and Keresztes (20I0) are not interested in functional-typological points of view, but rather they attempt to understand the origins of the Saami demonstratives (mostly represented by North Saami) mainly by comparing them with Finnic (Finnish), and they do this by clinging to the traditional principles of historical phonology only.

However, already Ultan (1978) has paid attention to the significant role of sound symbolism in spatial deixis, and new research has gradually confirmed his preliminary observations (e.g. most recently Johansson \& Zlatev 2013). In short, the sound symbolism in demonstratives is mainly connected to vowels in that proximal demonstratives tend to be associated with closed, front and unrounded vowels, whereas distal demonstratives are more prone to contain open, back and rounded vowels. The Saami languages are no exception, and it is especially notable in Table 8 that the distal 
demonstratives always have rounded back vowels, whereas the closest unrounded articulation is associated with the most proximal demonstratives - the addressee-oriented diet and tiet in North and Aanaar Saami, as well as the emphatically speaker-oriented tiet-aa 'this here' in Skolt Saami. Kulonen (2010: 96) notes that the situation is similar throughout the Uralic family. True, the most exceptional distal demonstrative $d u t$ /tuuh/ appears to go back to a form with a central vowel (see Section 3.I), but in the absence of $/ \mathrm{u} /$ in the autochthonous lexicon, the more original /tuuh/ (IPA/tu:h/) has been even more loaded with sound symbolism.

It appears that the role of sound symbolism in demonstratives is universally significant to the extent that it would be downright wrong to not take this into account in historical Uralistics as well. In fact, this might explain many of the difficulties and disagreements in attempts to reconstruct the Proto-Saami(-Finnic) demonstrative system, not to speak of more distant proto-languages. It is probable that none of the Saami demonstrative systems can ever be derived from Proto-Uralic or even Proto-Saami by referring to well-attested regular sound changes only.

Another neglected perspective on the development of distributives is that they always form a systematic whole in a language designed for effective communication. It is quite possible that such a system acts as a counterforce to regular sound changes, which in turn complicates straightforward reconstruction. From a more holistic point of view, it is possible to speculate that especially South Saami may have experienced a kind of chain shift, which has more or less simultaneously affected the entire demonstrative system and even other grammatical elements (cf. de Reuse 20oI). As seen in Section 3.3, dibte is not the only anaphoric demonstrative, but dohte (5) is also used. From a communicative perspective, this could be explained by the fact that dibte has also become a definite article with only faintly anaphoric function, as well as the default third-person pronoun, thus replacing the original third-person pronoun satne, which can nowadays be characterized as a logophoric pronoun (see Magga \& Magga 20I2: $5 \mathrm{I}-52,232-233)$. In a language with as many as four demonstrative pronouns, dibte has thus become unusually polysemous, which in turn may have resulted in increased use of dobte in functions for which other Saami languages rely on the cognates of dibte. The suggested semantic chain shift is schematized in Figure 2.

$\begin{array}{llll}\text { dohte } \\ \text { deictic } \rightarrow \begin{array}{l}\text { dohte } \\ \text { anaphoric } \\ \text { dibte }\end{array} & \rightarrow \text { dibte } \\ & \begin{array}{l}\text { third person } \\ \text { satne }\end{array} & \rightarrow & \\ & & \text { satne } \\ & & \text { logophoric }\end{array}$

Figure 2. Proposed semantic chain shift in South Saami demonstrative and personal pronouns. 
This paper has aimed to provide a concise picture of the demonstrative pronouns in six Saami languages, focusing on their deictic functions and bringing up certain previously ignored features. While the elements in question have been described mostly from a synchronic perspective, it is to be hoped that the observations and remarks presented here may also benefit typological research on demonstratives as well as future approaches to the historical development of Saami and other Uralic demonstratives.

\section{Nonstandard abbreviations used in glosses}

$\begin{array}{ll}\text { ADDR } & \text { addressee-oriented } \\ \text { AN } & \text { anaphoric } \\ \text { DISTI } & \text { distal (first-degree distance) } \\ \text { DIST2 } & \text { distal (second-degree distance) } \\ \text { DIST3 } & \text { distal (third-degree distance) } \\ \text { DPT } & \text { discourse particle }\end{array}$

$\begin{array}{ll}\text { GENACC } & \text { genitive-accusative } \\ \text { HES } & \text { hesitation pronoun } \\ \text { ILL } & \text { illative } \\ \text { INCH } & \text { inchoative } \\ \text { SPKR } & \text { speaker-oriented } \\ \text { SUP } & \text { superlative }\end{array}$

\section{References}

Авondolo, Daniel 1998: Introduction. - Daniel Abondolo (ed.), The Uralic languages. London: Routledge. I-42.

Antonova 2014 = Антонова, Сāнндрэ 20I4: Са̄мь-Рӯmm са̄ннб̆нэххък. Мурманск: ЛЕMA.

BERGSLAND, KNUT 1946: Roros-lappisk grammatikk. Et forsøk på strukturell språkbeskrivelse. Oslo: Aschehoug.

Bergsland, Knut i950: Remarques sur les pronoms démonstratifs lapons. - Commentationes Fenno-Ugricae in honorem Y. H. Toivonen. Mémoires de la Société FinnoOugrienne 98. Helsinki: Suomalais-Ugrilainen Seura. 27-35.

Collinder, Björn i949: The Lappish dialect of Jukkasjärvi. A morphological survey. Uppsala: Almqvist \& Wiksell.

Diessel, Holger 20I2: Deixis and demonstratives. - Claudia Maienborn, Klaus von Heusinger \& Paul Portner (eds.), Semantics: An international handbook of natural language meaning. Berlin: De Gruyter Mouton. 2407-2431.

Diessel, Holger 20I3: Distance contrasts in demonstratives. - Matthew S. Dryer \& Martin Haspelmath (eds.), The World Atlas of Language Structures Online. Leipzig: Max Planck Institute for Evolutionary Anthropology. 〈http://wals.info/chapter/4I > (30.6.2019).

Feist, Timothy 20i6: A grammar of Skolt Saami. Mémoires de la Société Finno-Ougrienne 273. Helsinki: Finno-Ugrian Society.

Guttorm, Outi 2009: Adnominála demonstratiivapronomenat muhtin davvisámegiel teavsttain. - Johanna Ijäs \& Nils Øivind Helander (eds.), Sábkavuoruin sábkan. Sámegiela ja sámi girjjálašvuođa mubtin áigeguovdilis dutkanfáttát. Guovdageaidnu: Sámi allaskuvla. II4-I25.

Guttorm, Outi 20I5: Davvisámegiela adnominála dat - demonstratiivadeterminánttas maiddái definihtta artihkalin? - Sámi diectalašáigećála 2/2015: 7-31. 
Guttorm, Outi 2019: Pohjoissaamen adnominaaliset demonstratiivipronominit nuorten radiokeskusteluissa. - Puhe ja kieli 39: 143-163.

GutTorm, Vesa 1992: Muhtin sátni davvisámegiela demonstratiivvain ja dat-pronomena funkšuvnnain. - Vesa Guttorm (ed.), Giellačállosat. Guovdageaidnu: Sámi Instituhtta. I-II.

ILW = Inarilappisches Wörterbuch. Herausgegeben von Erkki Itkonen unter Mitarbeit von Raija Bartens und Lea Laitinen. Helsinki: Suomalais-Ugrilainen Seura 1986-199I.

Jacobsen, Anna 1996 = JaAhkenelkien Aanna: Luste lobkedh. Kautokeino: Samisk utdanningsråd.

Jansson, Tove 2019A: Moodraitälvv. Sää'mte'ğğ.

Jansson, Tove 2019B: Tijdâtälvi. Sämitigge.

Johansson, Niklas \& Zlatev, Jordan 20I3: Motivations for sound symbolism in spatial deixis. A typological study of Ior languages. - The Public Journal of Semiotics 5: I: 3-20. $<$ https://journals.lub.lu.se/pjos/article/view/9668〉 (30.6.2019).

JuUtinen, Markus 20i6: Skalaariset partikkelit koltansaamessa. MA Thesis, University of Helsinki. 〈http://urn.fi/URN:NBN:fi:hulib-2016II032948> (30.6.2019).

Kåven, Brita et Al. 1995: Sámi-dáru sátnegirji. Kárášjohka: Davvi Girji.

Keresztes, LÁszló 20io: Ein Aspekt des Systems der Demonstrativpronomina im Saamischen (Lappischen). - Finnisch-Ugrische Mitteilungen 32/33: 291-296.

Kert 1971 = Керт, Георгий Мартынович 197і: Саамский язык (кильдинский диалект). Фонетика. Морфология. Синтаксис. Ленинград: Наука.

Kont, Karl 1970: Über die Demonstrativpronomina des Lappischen. - Congressus Tertius Internationalis Fenno-Ugristarum Tallinnae habitus 17.-23. VIII 1970: I. Acta linguistica. Tallinn: Valgus. 444-448.

Korhonen, Mikno \& Mosnikoff, Jouni \& Sammallahti, Pekna 1973: Koltansaamen opas. Castrenianumin toimitteita 4. Helsinki: Suomalais-Ugrilainen Seura.

Kulonen, Ulla-Maija 2005: Mutató névmások az uráliban és grammatikalizációjuk. Beatrix Oszkó \& Mária Sipos (eds.), Uráli grammatizáló. Budapest: MTA Nyelvtudományi Intézet. 207-213.

Kulonen, Ulla-Maija 20Io: Fonesteemit ja sananmuodostus. Suomen kontinuativisten U-verbijobdosten historiaa. Helsinki: Suomalaisen Kirjallisuuden Seura.

Kuruč 1985 = Куруч, Римма Дмитриевна 1985: Са̄мь-Рушщи соагкнэһкъ. Москва: Рушшш кйлл.

LarjavaAra, Matti 1986: Itämerensuomen demonstratiivit I. Karjala, aunus, lyydi ja vepsä. Helsinki: Suomalaisen Kirjallisuuden Seura.

LarjavaAra, Matti 2003: Demonstratiivit ja kieliopillistuminen. - Virittäjä IO7: 464-474.

Lehtiranta, Juhani 1992: Arjeploginsaamen äänne-ja taivutusopin pä̈̈piirteet. Mémoires de la Société Finno-Ougrienne 2I2. Helsinki: Suomalais-Ugrilainen Seura.

Magga, Ole Henrik 2013: Om sørsamisk språk og dets beskrivelse. - Aarjel-saemieh / Samer i sor II: 83-96.

Magga, Ole Henrik \& Magga, Lajla Mattsson 20I2: Sorsamisk grammatikk. Karasjok: Davvi Girji.

Moshnikoff, Satu \& Moshnikoff, Jouni \& Koponen, Eino 2009: Koltansaamen koulukielioppi. Säämǩiöl ǩöllvuä’ppes skoon'li vääras. Inari: Saamelaiskäräjät.

Nielsen, Konrad 1926: Larebok i lappisk. I. Grammatikk. Oslo: A. W. Brøgger.

Nielsen, Konrad 1932-1962: Lappisk ordbok. Grunnet på dialektene i Polmak, Karasjok og Kautokeino. Oslo: Aschehoug. 
Nielsen, Konrad 1947: Utslag av lappisk spesialiseringstendens. De mange pronominale stedsadverbier og bruken av dem. - Nils Lid (ed.), Lapponica. Studia Septentrionalia III. Oslo: Aschehoug. 45-68.

Olsen, Inger Margrethe 1994A: Noaide-Liissá. Kárášjohka: Davvi Girji.

Olsen, Inger Margrethe i994B: Ganij-Lijsá. Káráśjohka: Davvi Girji.

Olsen, Inger Margrethe 1994C: Saajue-Lejsa. Kárášjohka: Davvi Girji.

Olthuis, Marja-LiIsa 200o: Kielâoppâ. Inarinsaamen kielen kielioppi. Sämitigge.

De Reuse, Willem J. 20or: The Great Yupik Mood Swing, and its implications for the directionality of semantic change. - Mary Andronis et al. (eds.), CLS 37: The Panels. Chicago: Chicago Linguistic Society. 239-247.

RYDVing, HÅkAn 20I3: Words and varieties. Lexical variation in Saami. Mémoires de la Société Finno-Ougrienne 269. Helsinki: Finno-Ugrian Society.

Sammallahti, Pekna 2005: Láidehus sámegiela cealkkaoahpa dutkamii. Kárášjohka: Davvi Girji.

Sammallahti, Pekka \& Nickel, Klaus Peter 2006: Sámi-duiskka sátnegirji. Karasjok: Davvi Girji.

SIKOR. UiT The Arctic University of Norway and the Norwegian Saami Parliament's Saami Text Collection, Version 06.II.20I8. <http://gtweb.uit.no/korp/>

TEREŠKIN 2002 = Терешкин, Сергей Николаевич 2002: Йоканьгский диалект саамского языка. Санкт-Петербург: РГПУ им. А. И. Герцена.

Ultan, Russell 1978: Size-sound symbolism. - Joseph H. Greenberg (ed.), Universals of buman language 2. Phonology. Stanford: Stanford University Press. 527-568. 